\title{
Effect of the Matric Potential on Growth and Water, Nitrate and Potassium Absorption of Vegetables under Soilless Culture
}

\author{
Diego Alves Peçanha ${ }^{1}$ (]) Tatiana Pagan Loeiro da Cunha-Chiamolera ${ }^{2}$ (1) $\cdot$ Yasmina Chourak $^{2}$ (1) \\ Evelynn Yoselinn Martínez-Rivera² ${ }^{2}$ - Miguel Urrestarazu² ${ }^{2}$
}

Received: 24 June 2021 / Accepted: 14 September 2021 / Published online: 4 October 2021

(c) The Author(s) 2021

\begin{abstract}
To exploit the full potential of plants, it is essential to provide an adequate water balance during critical growth stages. With knowledge of the substrate's matric potential, it is possible to realistically measure the amount of water available to the plant. The objective of this research is to study the effect of the matric potential of the substrate on the growth of beans, lettuce, sweet peppers, watermelon, and cauliflower plants. The research goal was to evaluate the effect of the matric potential on the main fertigation parameters of horticultural plants. The plants were cultivated at the University of Almería (Spain) in a controlled chamber in a pot with $250 \mathrm{~mL}$ of coconut fiber substrate from block propagation. For treatments $\mathrm{T}_{15}, \mathrm{~T}_{30}, \mathrm{~T}_{45}$, and $\mathrm{T}_{60}$, new irrigation was applied when easily available water (EAW) depletion levels of 15, 30, 45, and 60\% were reached, respectively. The efficiency of the use of water (WUE), nitrate (NUE), and potassium (KUE) was measured. From $\mathrm{T}_{15}$ to $\mathrm{T}_{60}$, a significant effect was found for the absorption of water, nitrate and potassium, WUE, NUE, and KUE. $\mathrm{T}_{60}$ reduced the plant growth by half. The largest growth was between 15 and 30\% of the level of use of EAW. Two different models were constructed according to each plant. It is possible to have a small depletion in the available water and still have plant growth, if there is a balance between the air and water needs of the substrate.
\end{abstract}

Keywords Horticultural water management $\cdot$ Deficit irrigation $\cdot$ Irrigation water use efficiency $\cdot$ Water $\cdot$ Nitrate $\cdot$ Potassium absorption

\section{Introduction}

It is well-known that irrigation and fertigation are key factors influencing plant water status (Lu et al. 2019) and mineral nutrition. Substrate matric potential is a realistic criterion for measuring water availability to plants, as it constitutes the force with water held by its matrix (substrate particles and pore space) (Yadvinder-Singh et al. 2014) and can be measured by the well-known water release curve of the substrate (de Boodt et al. 1974). For a long time, a very low level of substrate matric potential ranging from -10 to $-100 \mathrm{~cm}$ of

Miguel Urrestarazu

mgavilan@ual.es

1 Departamento de Agronomia, Campus dos Goytacazes, Universidade Estadual do Norte Fluminense-Darcy Ribeiro (UENF), Rio de Janeiro 28013-602, Brazil

2 CIAMBITAL (Research Centre for Intensive Mediterranean Agrosystems and Agrifood Biotechnology), University of Almería, 04120 Almería, Spain a water column was recommended (de Boodt and Verdonck 1972) and later confirmed by other researchers for ornamental plants grown in soilless culture (Caron et al. 1998; Jobin et al. 2004; Londra et al. 2018). This range maintained the easily available water (EAW) and provided the necessary air between their solid particles.

During the last three decades, coconut coir has become a widely accepted inorganic and organic substrate substitute, both in ornamental and vegetable crops and in herbaceous and even woody crops (Abad et al. 2005; Evans and Stamps, 1996; Gallegos et al. 2020; Gallegos-Cedillo et al. 2018; Meerow 1995; Morales and Urrestarazu 2013; Morales et al. 2018; Moya et al. 2017; Pozo et al. 2015; Stamps and Evans 1997; Urrestarazu et al. 2008a; Urrestarazu et al. 2016; Nájera and Urrestarazu 2019). Models of (1) cultural management (Cunha-Chiamolera et al. 2017), (2) fertigation systems (Urrestarazu et al. 2015), and (3) in comparison to inorganic substrates (Pozo et al. 2014) have been developed using coir substrates as references. 
Soilless culture represents a valid opportunity for the horticultural production sector, especially in areas characterized by severe soil degradation, and limited water soilless culture is based on the comparison of the inputs (fertigation) with the outputs (drainage), which are volume, EC, and $\mathrm{pH}$ (Amalfitano et al. 2017; Carvalho et al. 2018; Kinoshita et al. 2016; Lee et al. 2017; Rodríguez et al. 2014a, 2015; Urrestarazu et al. 2019). There are few works published in relation to regulated deficit irrigation in vegetable crops under soilless culture (with a very lower matric potential), and the results show growth yield reduction in many cases and an increase in water use efficiency (Wang et al. 2012; Yang et al. 2017). Additionally, vegetable plants grown under soilless culture are very sensitive to water deficit stress (Ahmed et al. 2014; Urrestarazu 2015). However, there are very few works that define the frequency of irrigation based on a certain percentage of consumption of the available water per substrate and plant (Riviere et al. 1990), which is linked to the matric potential.

On the other hand, it is well known that potassium and nitrate are macronutrients that are more controlled and monitored in the practical management of fertigation in soilless culture (Adams and Ho 1989; Adams 1994; GallegosCedillo et al. 2016; Rodríguez et al. 2014a, 2014b; Wamser et al. 2017).

The objective of this study is to evaluate the effects of various levels of the substrate matric potential through the level of use of a determined EAW volume on (1) vegetative growth of vegetable plants, (2) water and mineral absorption, and (3) water and nutrient use efficiency of vegetable plants grown under substrate soilless culture.

\section{Materials and Methods}

\subsection{Vegetal Materials and Crop Conditions}

Five vegetable crops were grown in a controlled chamber at the University of Almeria (Spain) in independent experiments. Seedlings with 4 true leaves of bean (Phaseolus vulgaris L. cv Strike), lettuce (Lactuca sativa L. cv. Longifolia), sweet pepper (Capsicum annun cv. Kuman), watermelon (Citrullus lanatus (Thunb.) Matsum \& Nakai cv. Oneida), and cauliflower (Brassica oleracea L. cv. Bellamy) were transplanted into $250 \mathrm{ml}$ pots from block propagation.

The plants were grown in a chamber with a $16-8 \mathrm{~h}$ light-dark cycle, $25-20{ }^{\circ} \mathrm{C}$ day-night temperature, 55-75\% relative humidity, and $250 \mu \mathrm{mol} \mathrm{m} \mathrm{m}^{-2} \mathrm{~s}^{-1}$ photosynthetic photon flux density (400-700 nm) supplied by LED Sylvania Cool White lamps (Osram Sylvania Inc., Danvers, MA, USA) during a cycle of 60 days. The macro- and micronutrient compositions of the nutrient solution were similar to those reported by Sonneveld and Straver (1994).
The hydrological characteristics of the substrate used are shown in Fig. 1. To generate the water release curve, the concept described by de Boodt et al. (1974) was applied. The following volumes were calculated: effective total porosity (volumetric percentage of pore space), air volume after drainage (air content at 10-cm water suction, air capacity), easily available water (difference in the volumetric water content between $10-$ and $50-\mathrm{cm}$ water suction), buffering capacity (difference in the volumetric water content between 50 and $100 \mathrm{~cm}$ water suction), and hardly available water. Measurements were performed following European substrate regulations (AENOR 2012a). Other physical, physical-chemical, and chemical characteristics were determined under European substrate regulations (AENOR 2002a, 2002b, 2008a, 2008b, 2012a, 2012b, 2012c).

\subsection{Fertigation Treatments}

Four treatments were used. For the $\mathrm{T}_{15}, \mathrm{~T}_{30}, \mathrm{~T}_{45}$, and $\mathrm{T}_{60}$ treatments, new irrigation was applied when easily available water depletion levels of $15,30,45$, and $60 \%$ were reached, respectively (Fig. 1).

Loss transpiration was quantified by weight measurements with a two-tenth precision analytical scale model, Ohaus Adventurer AX, with a resolution of $0.1 \mathrm{mg}$. Each new fertigation consisted of the supply transpired volume of the nutrient solution plus $20 \%$ to maintain the nutrient balance in the substrate (Rodríguez et al. 2014b).

\subsubsection{Analysis and Harvest Sampling}

The volume, $\mathrm{pH}$, electrical conductivity (EC), and nitrate and potassium contents of the drainage were measured daily in each pot with a container that was adapted to its morphology. The $\mathrm{pH}$ and electrical conductivity (EC) were

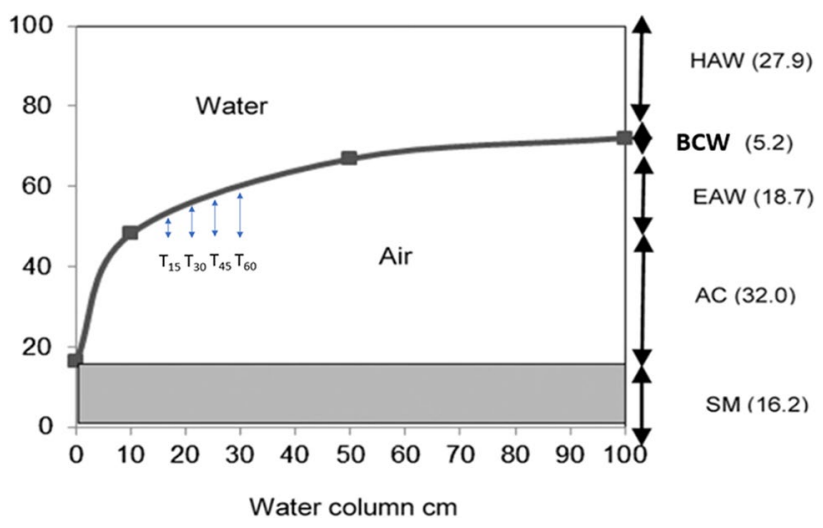

Fig. 1 Water release curve of coir substrate in vol (based on de Boodt et al. 1974). HAW, hardly available water; BCW, buffering capacity water; EAW, easily available water; AC, air capacity; SM, solid matter 
monitored using systems from HORIBA Ltd. (LAQUAact PC110-K).

The contents of nitrate and potassium were measured with systems from HORIBA Ltd. Japan (LAQUAtwin B-741 and LAQUAtwin B-731, respectively). The absorption of nitrates and potassium in mmol.plant ${ }^{-1}$ was quantified based on the balance between input and output (Urrestarazu et al. 2005, 2008b).

Water (WUE), nitrate (NUE), and potassium (KUE) use efficiencies were calculated by dividing the total dry weight of plants by the uptake volumes of water (L), nitrate (mmol), and potassium (mmol), respectively.

\subsection{Experimental Design and Statistical Analysis}

The experiment was conducted using a split-plot design with three blocks per treatment and four plants per treatment in each treatment using a completely random design.

Statistical analysis of different parameters was performed using the SPSS software (Statistics Package). ANOVA was performed and a Tukey test at the $P \leq 0.05$ level of significance was used to determine if significant parameter differences existed among different treatments. A quadratic linear equation and its $R^{2}$ and $P$ were also considered (Fig. 4).

\section{Results}

\subsection{Effect on Fertigation Parameters and Mineral Absorption}

Table 1 shows the $\mathrm{pH}$ and $\mathrm{EC}$ of drainage and the nitrate and potassium absorption. There was no significant difference in $\mathrm{pH}$ for any crop. For all crops, significant differences between the treatments were recorded in the EC of drainage and absorption of water, nitrate, and potassium. The highest EC values found were consistent with the highest potassium and nitrate absorption. The highest water absorption was recorded when new fertigation was supplied after $15\left(\mathrm{~T}_{15}\right)$ or $30 \%\left(\mathrm{~T}_{30}\right)$ (in the case of cauliflower) of easily available water was lost by plant transpiration.

Except for the pepper, in general, from $\mathrm{T}_{15}$ to $\mathrm{T}_{60}$, a significant correlation between water absorption and mineral absorption (expressed as nitrate and potassium uptake) was found (Fig. 2) (Amalfitano et al. 2017). In pepper, while the reduction in water was higher $\left(34 \%\right.$, from $\mathrm{T}_{15}$ to $\mathrm{T}_{60}$ ), the lowest variation in $\mathrm{EC}$ and reduction in absorption nitrate and potassium (11 and 15\%, respectively) of all plants were recorded for the same treatments.

Table 1 Fertigation parameters of vegetables grown in coir according to when the new watering is supplied after a certain percentage of transpired volume (\%) from easily available water

\begin{tabular}{|c|c|c|c|c|c|c|}
\hline & \multirow[b]{3}{*}{$\%$} & & & \multicolumn{3}{|l|}{ Uptake } \\
\hline & & \multicolumn{2}{|c|}{ Drainage } & \multirow{2}{*}{$\begin{array}{l}\mathrm{mL} \mathrm{plant}^{-1} \\
\text { Water }\end{array}$} & \multicolumn{2}{|l|}{ mmol plant ${ }^{-1}$} \\
\hline & & $\mathrm{pH}$ & $\mathrm{EC}\left(\mathrm{dS} \mathrm{m} \mathrm{m}^{-1}\right)$ & & $\mathrm{NO}_{3}^{-}$ & $\mathrm{K}^{+}$ \\
\hline \multirow[t]{4}{*}{ Bean } & 15 & $5.75 \mathrm{a}$ & $7.30 \mathrm{a}$ & $456 \mathrm{~b}$ & $14.48 \mathrm{a}$ & $8.50 \mathrm{a}$ \\
\hline & 30 & $5.85 \mathrm{a}$ & $7.48 \mathrm{a}$ & $504 \mathrm{a}$ & $14.19 \mathrm{a}$ & $8.49 \mathrm{a}$ \\
\hline & 45 & $6.00 \mathrm{a}$ & $4.61 \mathrm{c}$ & $357 \mathrm{c}$ & $10.62 \mathrm{~b}$ & $6.53 \mathrm{~b}$ \\
\hline & 60 & $6.03 \mathrm{a}$ & $3.40 \mathrm{~d}$ & $319 \mathrm{~d}$ & $8.64 \mathrm{c}$ & $5.63 \mathrm{c}$ \\
\hline \multirow[t]{4}{*}{ Lettuce } & 15 & $5.24 \mathrm{a}$ & $8.04 \mathrm{a}$ & $732 \mathrm{a}$ & $3.12 \mathrm{c}$ & $2.69 \mathrm{c}$ \\
\hline & 30 & $5.19 \mathrm{a}$ & $6.61 b c$ & $589 \mathrm{~b}$ & $18.93 \mathrm{a}$ & $15.56 \mathrm{a}$ \\
\hline & 45 & $5.33 \mathrm{a}$ & $7.66 \mathrm{~b}$ & $414 \mathrm{c}$ & $10.60 \mathrm{~b}$ & $9.23 \mathrm{~b}$ \\
\hline & 60 & $5.39 \mathrm{a}$ & $5.61 \mathrm{c}$ & $352 \mathrm{~d}$ & $5.40 \mathrm{c}$ & $2.56 \mathrm{c}$ \\
\hline \multirow[t]{4}{*}{ Pepper } & 15 & $6.20 \mathrm{a}$ & $5.29 \mathrm{c}$ & $1151 \mathrm{a}$ & $6.31 \mathrm{a}$ & $3.34 \mathrm{a}$ \\
\hline & 30 & $6.16 \mathrm{ab}$ & $5.95 \mathrm{~b}$ & $920 \mathrm{~b}$ & $4.49 \mathrm{c}$ & $2.15 \mathrm{c}$ \\
\hline & 45 & $6.10 \mathrm{~b}$ & $6.43 \mathrm{a}$ & $860 \mathrm{c}$ & $3.27 \mathrm{~d}$ & $1.59 \mathrm{~d}$ \\
\hline & 60 & $6.22 \mathrm{a}$ & $4.84 \mathrm{~d}$ & $761 \mathrm{~b}$ & $5.63 \mathrm{~b}$ & $2.81 \mathrm{~b}$ \\
\hline \multirow[t]{4}{*}{ Watermelon } & 15 & $5.24 \mathrm{a}$ & $8.04 \mathrm{a}$ & $732 \mathrm{a}$ & $3.12 \mathrm{c}$ & $2.69 \mathrm{c}$ \\
\hline & 30 & $5.19 \mathrm{a}$ & $6.61 \mathrm{bc}$ & $589 \mathrm{~b}$ & $18.93 \mathrm{a}$ & $15.56 \mathrm{a}$ \\
\hline & 45 & $5.33 \mathrm{a}$ & $7.66 \mathrm{~b}$ & $414 \mathrm{c}$ & $10.60 \mathrm{~b}$ & $9.23 \mathrm{~b}$ \\
\hline & 60 & $5.39 \mathrm{a}$ & $5.61 \mathrm{c}$ & $352 \mathrm{~d}$ & $5.40 \mathrm{c}$ & $2.56 \mathrm{c}$ \\
\hline \multirow[t]{4}{*}{ Cauliflower } & 15 & $5.91 \mathrm{a}$ & $4.46 \mathrm{~b}$ & $469 \mathrm{a}$ & $3.78 \mathrm{a}$ & $1.51 \mathrm{a}$ \\
\hline & 30 & $5.84 \mathrm{~b}$ & $4.71 \mathrm{ab}$ & $347 \mathrm{~b}$ & $2.47 \mathrm{~b}$ & $0.87 \mathrm{~b}$ \\
\hline & 45 & $5.92 \mathrm{a}$ & $5.02 \mathrm{a}$ & $299 \mathrm{c}$ & $1.99 \mathrm{c}$ & $0.69 \mathrm{c}$ \\
\hline & 60 & $5.82 \mathrm{~b}$ & $3.69 \mathrm{c}$ & $267 \mathrm{~d}$ & $1.71 \mathrm{~d}$ & $0.76 \mathrm{c}$ \\
\hline
\end{tabular}

Different letters indicate significant difference at $P \leq 0.05$ according to Tukey's test. $n=4$ 


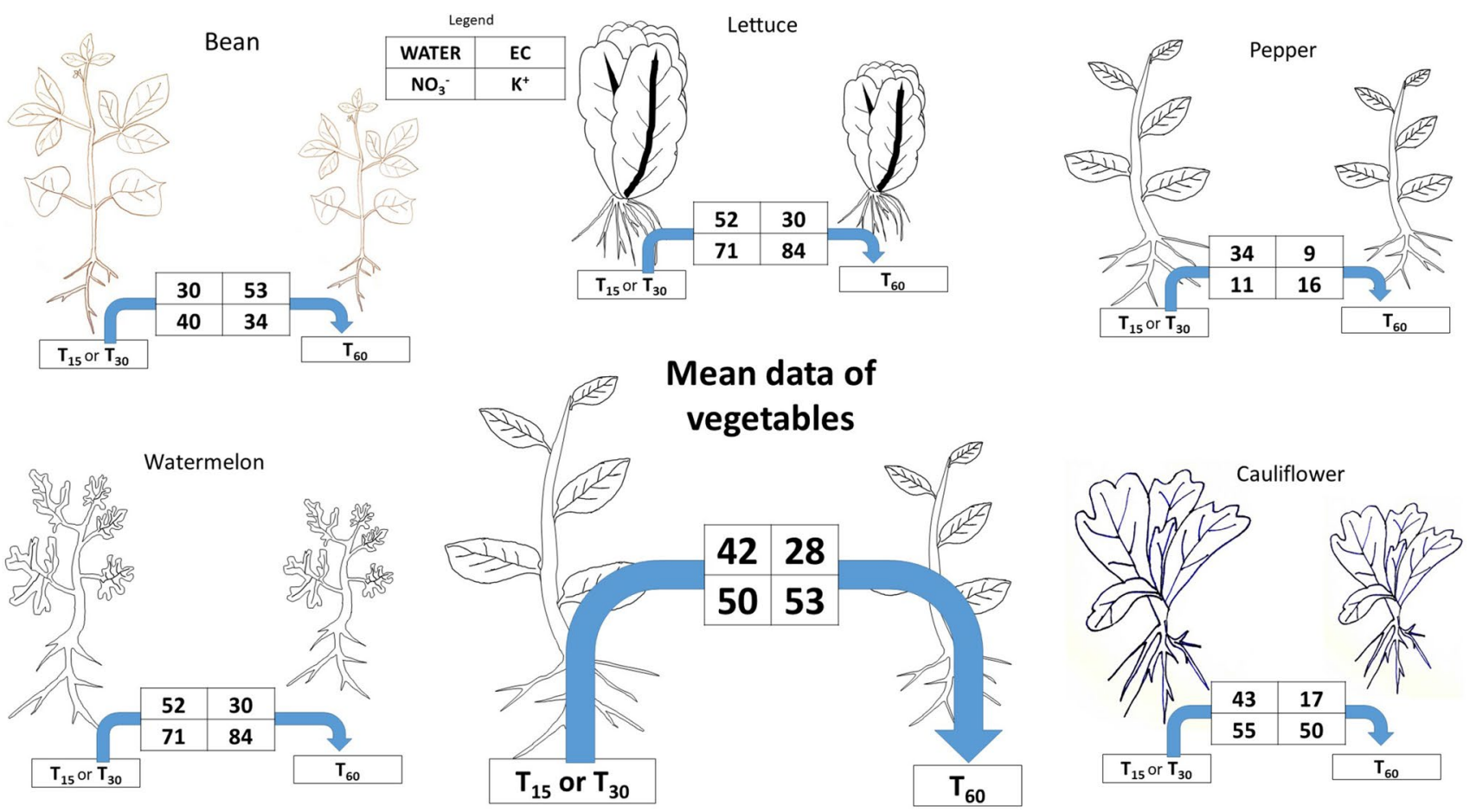

Fig. 2 Significant percentage of reduction (\%) of water, nitrate, and potassium absorption and drainage electric conductivity (EC) that occurs when a volume of fertigation is supplied after $15\left(\mathrm{~T}_{15}\right)$ or $30 \%\left(\mathrm{~T}_{30}\right)$ of easily available water has been transpired by the vegetable plants

\subsection{Effect on Growth Parameters}

In general, as the water needed for the plants was absorbed from a greater depletion of the EAW (greater matric potential, from $\mathrm{T}_{15}$ to $\mathrm{T}_{60}$ ), the growth parameters decreased significantly (Table 2).

Except for cauliflower, the greatest total fresh and dry weight and leaf area were found in $\mathrm{T}_{15}$.

From $T_{15}$ to $T_{60}$, the smallest and largest decreases in growth were recorded in bean and pepper, respectively (Figs. 2 and 3). There were 49,51, and 59\% average decrease in five vegetables for their root, stem, and leaf dry weights, respectively.

\subsection{Effect on the Use Efficiency of Fertigation Inputs}

Except for pepper, the best use efficiency of water (WUE) and mineral absorption (NUE and KUE) was found with $\mathrm{T}_{15}$ and/or $\mathrm{T}_{30}$. In pepper plants, $\mathrm{T}_{60}$ had the best values for WUE, NUE, and KUE (Table 3). An et al. (2021) found similar results in the crop of Cymbidium in the WUE using coir as the substrate.

\subsection{Model of Growth as a Function of Matric Potential}

Figure 4 shows a clear and significant trend toward growth reduction even when lower matric potential in soilless culture is used. Except for cauliflower, $\mathrm{T}_{15}$ recorded the best vegetative growth. Cauliflower had its best growth at $\mathrm{T}_{30}$, probably because a benefit is found when root aeration is improved (Heuberger et al. 2001) and because cauliflower is the plant most sensitive to air capacity within the evaluated crops.

Figure 4E shows the average dry weight reduction as fertigation was delayed as a function of the depletion of EAW, while some plants, such as cauliflower, reached their optimum at $30 \%$ depletion.

\section{Discussion}

\subsection{Effect on Fertigation Parameters and Mineral Absorption}

The $\mathrm{pH}$ and electrical conductivity (EC) of drainage are parameters used to control and feedback the management of nutrient solution and fertigation (Urrestarazu 2015).

In tomato plants, similar results to those found in Table 1 were published on $\mathrm{pH}$ and the correlation between drainage EC and water uptake (Gallegos-Cedillo et al. 2016; Rodriguez et al. 2014b). Because of Adams and Ho (1989) and Adams (1994), it is well-known that the major absorption of anions and cations are nitrate and potassium, respectively; this is probably the reason for this positive correlation found 
Table 2 Growth parameters of vegetables grown in coir according to when the new watering is supplied after a certain percentage of transpired volume (\%) from easily available water

\begin{tabular}{|c|c|c|c|c|c|c|}
\hline & & g plant $^{-1}$ & & & & $\mathrm{~cm}^{2}$ plant $^{-1}$ \\
\hline & $\%$ & Root & Stem & Leaf & Total & Leaf area \\
\hline Fresh weight & & & & & & \\
\hline Bean & 15 & $2.53 \mathrm{~b}$ & $4.96 \mathrm{a}$ & $9.66 \mathrm{a}$ & $17.15 \mathrm{a}$ & $1025.1 \mathrm{a}$ \\
\hline & 30 & $2.79 \mathrm{a}$ & $5.40 \mathrm{a}$ & $8.22 \mathrm{~b}$ & $16.42 \mathrm{~b}$ & $903.3 \mathrm{~b}$ \\
\hline & 45 & $2.25 \mathrm{~b}$ & $4.59 \mathrm{a}$ & $7.57 \mathrm{c}$ & $14.40 \mathrm{c}$ & $840.2 \mathrm{c}$ \\
\hline & 60 & $2.36 \mathrm{~b}$ & $4.99 \mathrm{a}$ & $7.44 \mathrm{c}$ & $14.78 \mathrm{c}$ & $828.7 \mathrm{~d}$ \\
\hline Lettuce & 15 & $7.77 \mathrm{a}$ & $2.42 \mathrm{a}$ & $10.58 \mathrm{a}$ & $20.77 \mathrm{a}$ & $342.7 \mathrm{a}$ \\
\hline & 30 & $5.41 \mathrm{~b}$ & $1.64 \mathrm{~b}$ & $8.62 \mathrm{~b}$ & $15.67 \mathrm{~b}$ & $232.9 \mathrm{~b}$ \\
\hline & 45 & $3.54 \mathrm{~b}$ & $1.21 \mathrm{c}$ & $6.46 \mathrm{c}$ & $11.21 \mathrm{c}$ & $185.6 \mathrm{c}$ \\
\hline & 60 & $3.94 \mathrm{~b}$ & $1.17 \mathrm{c}$ & $6.31 \mathrm{c}$ & $11.41 \mathrm{c}$ & $166.9 \mathrm{~d}$ \\
\hline Pepper & 15 & $5.58 \mathrm{a}$ & $1.93 \mathrm{a}$ & $23.56 \mathrm{a}$ & $31.07 \mathrm{a}$ & $739.8 \mathrm{a}$ \\
\hline & 30 & $4.24 \mathrm{~b}$ & $1.15 \mathrm{~b}$ & $17.44 \mathrm{~b}$ & $22.82 \mathrm{~b}$ & $544.8 \mathrm{~b}$ \\
\hline & 45 & $2.63 \mathrm{c}$ & $1.04 \mathrm{c}$ & $12.82 \mathrm{c}$ & $16.49 \mathrm{c}$ & $474.9 \mathrm{c}$ \\
\hline & 60 & $1.29 \mathrm{~d}$ & $0.48 \mathrm{~d}$ & $7.33 \mathrm{~d}$ & $9.09 \mathrm{~d}$ & $263.2 \mathrm{~d}$ \\
\hline Watermelon & 15 & $6.80 \mathrm{a}$ & $5.48 \mathrm{a}$ & $12.09 \mathrm{a}$ & $24.37 \mathrm{a}$ & $216.5 \mathrm{a}$ \\
\hline & 30 & $6.14 b$ & $3.21 \mathrm{~b}$ & $9.11 \mathrm{~b}$ & $18.46 \mathrm{~b}$ & $193.9 \mathrm{~b}$ \\
\hline & 45 & $4.07 \mathrm{c}$ & $3.05 \mathrm{~b}$ & $7.91 \mathrm{~b}$ & $15.02 \mathrm{c}$ & $151.3 \mathrm{c}$ \\
\hline & 60 & $3.35 \mathrm{~d}$ & $2.38 \mathrm{c}$ & $4.63 \mathrm{c}$ & $10.36 \mathrm{~d}$ & $132.8 \mathrm{~d}$ \\
\hline Cauliflower & 15 & $2.11 \mathrm{a}$ & $3.22 \mathrm{~b}$ & $11.03 \mathrm{a}$ & $16.37 \mathrm{a}$ & $109.5 \mathrm{~b}$ \\
\hline & 30 & $2.05 \mathrm{a}$ & $4.14 \mathrm{a}$ & $11.54 \mathrm{a}$ & $17.73 \mathrm{a}$ & $152.1 \mathrm{a}$ \\
\hline & 45 & $1.76 \mathrm{ab}$ & $1.92 \mathrm{c}$ & $8.34 \mathrm{~b}$ & $12.01 \mathrm{~b}$ & $93.2 \mathrm{~b}$ \\
\hline & 60 & $1.24 \mathrm{~b}$ & $1.23 \mathrm{c}$ & $4.36 \mathrm{c}$ & $6.83 \mathrm{c}$ & $62.8 \mathrm{c}$ \\
\hline Dry weight & & & & & & \\
\hline Bean & 15 & $0.29 \mathrm{bc}$ & $0.55 \mathrm{a}$ & $0.79 \mathrm{a}$ & $1.48 \mathrm{a}$ & \\
\hline & 30 & $0.35 \mathrm{~b}$ & $0.52 \mathrm{~b}$ & $0.71 \mathrm{~b}$ & $1.40 \mathrm{~b}$ & \\
\hline & 45 & $0.48 \mathrm{a}$ & $0.43 \mathrm{c}$ & $0.59 \mathrm{c}$ & $1.26 \mathrm{c}$ & \\
\hline & 60 & $0.32 \mathrm{bc}$ & $0.42 \mathrm{c}$ & $0.58 \mathrm{c}$ & $1.16 \mathrm{~d}$ & \\
\hline Lettuce & 15 & $0.92 \mathrm{a}$ & $0.46 \mathrm{a}$ & $1.87 \mathrm{a}$ & $3.24 \mathrm{a}$ & \\
\hline & 30 & $0.56 \mathrm{~b}$ & $0.31 \mathrm{~b}$ & $1.46 \mathrm{~b}$ & $2.32 \mathrm{~b}$ & \\
\hline & 45 & $0.44 \mathrm{~b}$ & $0.27 \mathrm{~b}$ & $1.24 \mathrm{~b}$ & $1.96 \mathrm{~b}$ & \\
\hline & 60 & $0.43 \mathrm{~b}$ & $0.26 \mathrm{~b}$ & $1.24 \mathrm{~b}$ & $1.93 \mathrm{~b}$ & \\
\hline Pepper & 15 & $0.29 \mathrm{a}$ & $0.08 \mathrm{a}$ & $1.23 \mathrm{a}$ & $1.61 \mathrm{a}$ & \\
\hline & 30 & $0.22 \mathrm{ab}$ & $0.06 \mathrm{~b}$ & $0.99 \mathrm{~b}$ & $1.28 \mathrm{~b}$ & \\
\hline & 45 & $0.13 \mathrm{~b}$ & $0.05 \mathrm{~b}$ & $0.66 \mathrm{c}$ & $0.84 \mathrm{c}$ & \\
\hline & 60 & $0.10 \mathrm{~b}$ & $0.03 \mathrm{c}$ & $0.46 \mathrm{c}$ & $0.60 \mathrm{c}$ & \\
\hline Watermelon & 15 & $0.68 \mathrm{a}$ & $0.71 \mathrm{a}$ & $0.79 \mathrm{a}$ & $2.17 \mathrm{a}$ & \\
\hline & 30 & $0.61 \mathrm{a}$ & $0.42 \mathrm{~b}$ & $0.59 \mathrm{~b}$ & $1.63 \mathrm{~b}$ & \\
\hline & 45 & $0.40 \mathrm{~b}$ & $0.37 \mathrm{~b}$ & $0.51 \mathrm{~b}$ & $1.29 \mathrm{c}$ & \\
\hline & 60 & $0.33 \mathrm{~b}$ & $0.31 \mathrm{~b}$ & $0.30 \mathrm{c}$ & $0.94 \mathrm{~d}$ & \\
\hline Cauliflower & 15 & $0.15 \mathrm{ab}$ & $0.29 \mathrm{~b}$ & $0.89 \mathrm{bc}$ & $1.34 \mathrm{~b}$ & \\
\hline & 30 & $0.16 \mathrm{a}$ & $0.35 \mathrm{a}$ & $1.25 \mathrm{a}$ & $1.76 \mathrm{a}$ & \\
\hline & 45 & $0.14 \mathrm{abc}$ & $0.19 \mathrm{c}$ & $0.95 \mathrm{~b}$ & $1.28 \mathrm{~b}$ & \\
\hline & 60 & $0.12 \mathrm{c}$ & $0.17 \mathrm{c}$ & $0.62 \mathrm{c}$ & $0.91 \mathrm{c}$ & \\
\hline
\end{tabular}

Different letters indicate significant difference at $P \leq 0.05$ according to Tukey's test. $n=4$ between drainage EC and mineral absorption of nitrate and potassium.

Sweet pepper was the vegetable with the lowest loss of nitrate and potassium absorption under the highest matric potential $\left(\mathrm{T}_{60}\right)$.
The lowest loss of water absorption and growth was recorded for beans (Fig. 2), which agrees with the result published by Karimzadeh-Soureshjani et al. (2019), who attributed various mechanisms of this plant to escape water stress or water deficit. 

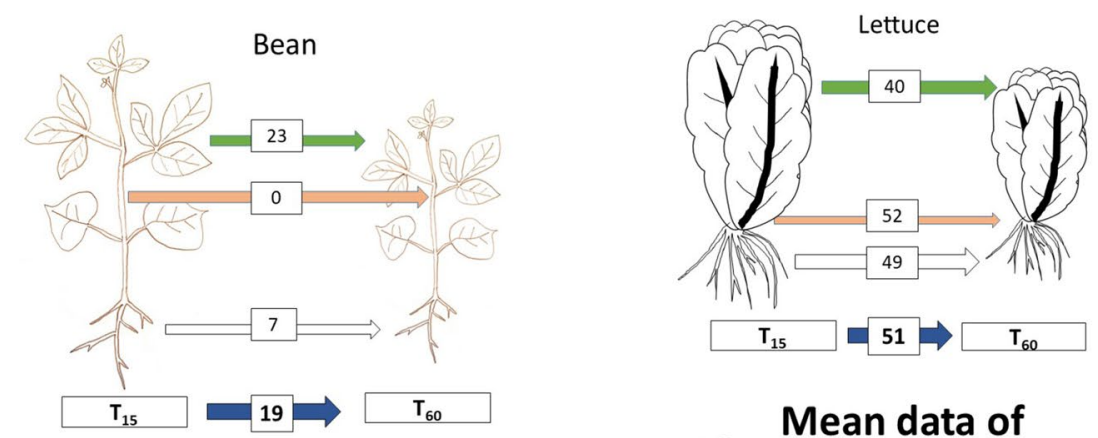

Mean data of vegetables
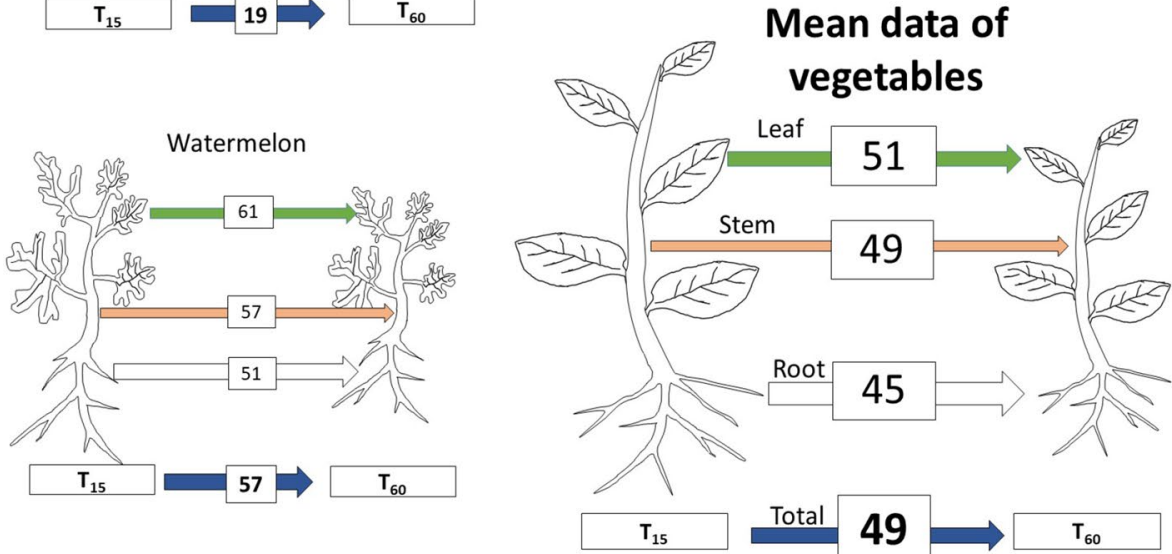
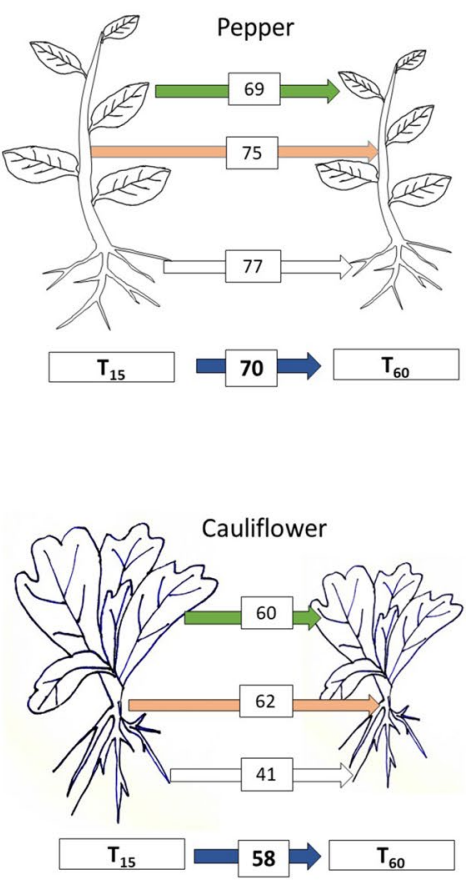

Fig. 3 Significant percentage of reduction (\%) in dry weight growth (leaf, stem, root, and total weight) that occurs when a volume of fertigation is supplied after $15 \%\left(\mathrm{~T}_{15}\right)$ or $60 \%\left(\mathrm{~T}_{60}\right)$ of easily available water has been transpired by the plant

\subsection{Effect on Growth Parameters}

Water availability mostly affects the growth of leaves and roots, photosynthesis and dry mater accumulation (Blum 1996). Similar results to our vegetables were found by Riviere et al. (1990) in shrubs and conifers, where the best growth was recorded under high frequent irrigation and the adjustment of the amount of volume to the needs of plants and aeration. Additionally, in general, the best growth results of coir-grown Cymbidium were found when the irrigation system was within the EAW (An et al. 2021).

The higher energy required for the same water uptake with increasing matric potential between the $T_{15}$ and $T_{60}$ treatments led to a significant decrease in growth for all vegetables.

\subsection{Effect on the Use Efficiency of Fertigation Inputs}

It is well-known that water and plant nutrients play a very important role in enhancing water and mineral nutrient use efficiency under limited water supply and other agrosystems (Waraich et al. 2011). Therefore, different fertigation regimes for each crop can be regulated to improve the use efficiency of the different fertigation inputs, as published by Wang et al. (2012) and Yang et al. (2017).
Table 3 Water (WUE), nitrate (NUE), and potassium (KUE) use efficiency of vegetables grown in coir according to when the new watering is supplied after a certain percentage of transpired volume (\%) by the plant from easily available water of the substrate

\begin{tabular}{lllll}
\hline \multirow{2}{*}{ Bean } & $\%$ & WUE & NUE & KUE \\
\hline \multirow{4}{*}{ Lettuce } & 15 & $0.31 \mathrm{ab}$ & $9.78 \mathrm{ab}$ & $5.74 \mathrm{ab}$ \\
& 30 & $0.36 \mathrm{a}$ & $10.14 \mathrm{a}$ & $6.06 \mathrm{a}$ \\
& 45 & $0.28 \mathrm{~b}$ & $8.43 \mathrm{~b}$ & $5.18 \mathrm{~b}$ \\
& 60 & $0.28 \mathrm{~b}$ & $7.45 \mathrm{bc}$ & $4.85 \mathrm{c}$ \\
Pepper & 15 & $0.23 \mathrm{ab}$ & $0.96 \mathrm{~d}$ & $0.83 \mathrm{~d}$ \\
& 30 & $0.25 \mathrm{a}$ & $8.16 \mathrm{a}$ & $6.71 \mathrm{a}$ \\
& 45 & $0.21 \mathrm{bc}$ & $5.41 \mathrm{~b}$ & $4.71 \mathrm{~b}$ \\
& 60 & $0.18 \mathrm{c}$ & $2.80 \mathrm{c}$ & $1.33 \mathrm{c}$ \\
Watermelon & 15 & $0.71 \mathrm{~b}$ & $3.92 \mathrm{~b}$ & $2.07 \mathrm{~b}$ \\
& 30 & $0.72 \mathrm{~b}$ & $3.51 \mathrm{~b}$ & $1.68 \mathrm{c}$ \\
& 45 & $1.02 \mathrm{a}$ & $3.89 \mathrm{~b}$ & $1.89 \mathrm{bc}$ \\
& 60 & $1.27 \mathrm{a}$ & $9.38 \mathrm{a}$ & $4.68 \mathrm{a}$ \\
& 15 & $0.34 \mathrm{a}$ & $1.44 \mathrm{~d}$ & $1.24 \mathrm{~d}$ \\
& 30 & $0.36 \mathrm{a}$ & $11.61 \mathrm{a}$ & $9.55 \mathrm{a}$ \\
& 45 & $0.32 \mathrm{a}$ & $8.22 \mathrm{ab}$ & $7.16 \mathrm{~b}$ \\
& 60 & $0.37 \mathrm{a}$ & $5.74 \mathrm{c}$ & $2.72 \mathrm{c}$ \\
& 15 & $0.35 \mathrm{ab}$ & $2.82 \mathrm{a}$ & $1.13 \mathrm{a}$ \\
& 30 & $0.20 \mathrm{c}$ & $1.40 \mathrm{c}$ & $0.49 \mathrm{c}$ \\
& 45 & $0.23 \mathrm{bc}$ & $1.55 \mathrm{bc}$ & $0.54 \mathrm{bc}$ \\
& 60 & $0.29 \mathrm{~b}$ & $1.88 \mathrm{~b}$ & $0.84 \mathrm{ab}$ \\
\hline
\end{tabular}

Different letters indicate significant difference at $P \leq 0.05$ according to Tukey's test. $n=4$ 
Fig. 4 Total dry weight (g plant $^{-1}$ ) as a function of when the new watering is supplied after a lost volume percentage $(\%)$ of easily available water from the substrate by plant transpiration. $* * *, * *$ indicate $P \leq 0.01$ and 0.05 , respectively
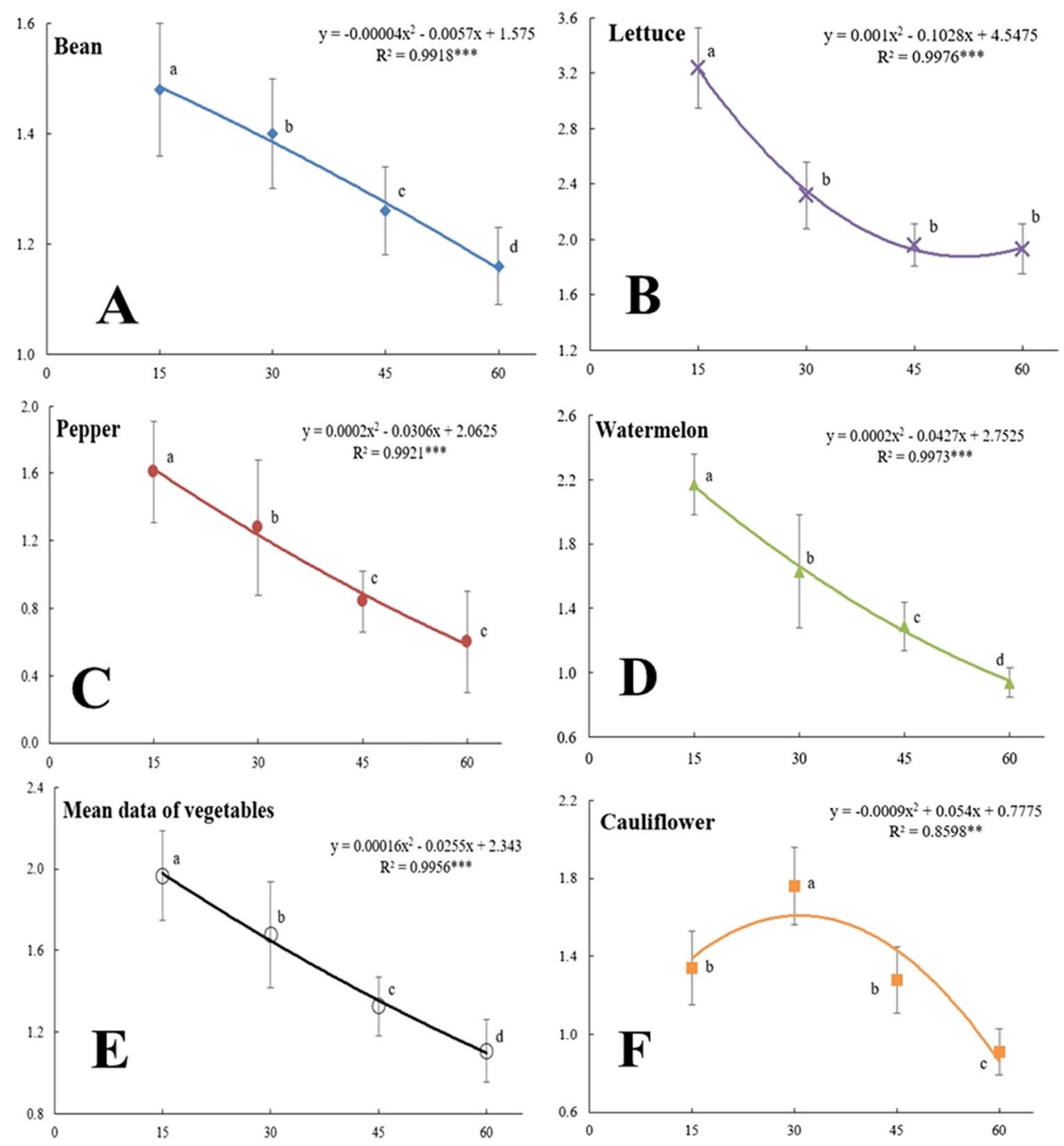

\subsection{Model of Growth as a Function of Matric Potential}

Based on the traditional model for crop salt tolerance by Maas and Hoffman (1977), another model has been described where zero growth and optimal range are reached and a subsequent threshold point with a decrease in growth is reached (Sonneveld and Voogt 2009). If this salinity tolerance model was compared with the matric potential model, only the behavior of cauliflower was coincident, probably to maintain the air-water availability equilibrium, while the rest of the vegetables had the best fit for a quadratic equation, as shown in Fig. 4E, where the water availability under a very lower matric potential was the limiting factor. If only $15-30 \%$ is used, the result will depend on the balance between the needs of air and water from the substrate for each plant.

More research on a larger number of ornamental and horticultural crops and their phenological stages according to horticultural objectives is required. A certain degree of stress through matric potential could be a good tool to control the balance between vegetative and fruiting development, especially in crops whose usable products are fruit or seeds.

\section{Conclusion}

When $60 \%$ of substrate easily available water is used in a crop unit of soilless culture before a new fertigation it supplies, there is a reduction in the vegetative growth of the vegetable by an average of approximately $50 \%$, with the smallest reduction for the root (45\%) and the largest for the leaves $(51 \%)$.

There was a high and significant correlation between the increased energy required to absorb water from treatments $\mathrm{T}_{15}$ to $\mathrm{T}_{60}$ and the decrease in growth that occurred in all plants. Based on a regression analysis, a specific model for each vegetable, one medium for all, was developed. The models showed a very close correlation between the different fertigation regimes and growth for all vegetables. 
Funding Open Access funding provided thanks to the CRUE-CSIC agreement with Springer Nature.

\section{Declarations}

Conflict of Interest The authors declare no competing interests.

Open Access This article is licensed under a Creative Commons Attribution 4.0 International License, which permits use, sharing, adaptation, distribution and reproduction in any medium or format, as long as you give appropriate credit to the original author(s) and the source, provide a link to the Creative Commons licence, and indicate if changes were made. The images or other third party material in this article are included in the article's Creative Commons licence, unless indicated otherwise in a credit line to the material. If material is not included in the article's Creative Commons licence and your intended use is not permitted by statutory regulation or exceeds the permitted use, you will need to obtain permission directly from the copyright holder. To view a copy of this licence, visit http://creativecommons.org/licenses/by/4.0/.

\section{References}

Abad M, Forne F, Carrión C, Noguera V, Noguera P, Maquieira A, Puchades R (2005) Physical properties of various coconut coir dusts compared to peat. HortScience 40:2138-2144. https://doi. org/10.21273/HORTSCI.40.7.2138

Adams P (1994) Nutrition of greenhouse vegetables in NFT and hidroponic systems. Acta Hortic. 361:245-257. https://doi.org/ 10.17660/ActaHortic.1994.361.23

Adams P, Ho LC (1989) Effects of constant and fluctuating salinity on the yield, quality and calcium status of tomatoes. J Hortic Sci 64:725-732. https://doi.org/10.1080/14620316.1989.11516015

AENOR (2002a) UNE-EN 13652:2002. Mejoradores de suelo y sustratos de cultivo. Extracción de nutrientes y elementos solubles en agua. [Soil improvers and growing media. Extraction of nutrients and water soluble elements].

AENOR (2002b) UNE-EN 13650 (modificado). Mejoradores de suelo y sustratos de cultivo. Extracción de elementos solubles en agua regia. [Soil improvers and growing media. Extraction of soluble elements in regia water]

AENOR (2008a) UNE-EN 15428:2008. Mejoradores de suelo y sustratos de cultivo. Determinación de la granulometría de las partículas. [Soil improvers and growing media.Determination of particle size]

AENOR (2008b) UNE-EN 13040:2008. Mejoradores de suelo y sustratos de cultivo. Preparación de la muestra para ensayos físicos y químicos. Determinación del contenido de materia seca, del contenido de humedad y de la densidad aparente compactada en laboratorio. [Soil improvers and growing media. Sample preparation for physical and chemical tests. Determination of dry matter content, moisture content and compacted bulk density in laboratory]

AENOR (2012a) UNE-EN 13041:2012. Mejoradores de suelo y sustratos de cultivo. Determinación de las propiedades físicas. Densidad aparente seca, volumen de aire, volumen de agua, valor de contracción y porosidad total. [Soil improvers and growing media. Determination of physical properties. Dry bulk density, air volume, water volume, shrinkage value and total porosity]

AENOR (2012b) UNE-EN 13037:2012. Mejoradores del suelo y sustratos de cultivo. Determinación del $\mathrm{pH}$. [Soil improvers and growing media. Determination of $\mathrm{pH}$ ]

AENOR (2012c) UNE-EN 13038:2012. Mejoradores del suelo y sustratos de cultivo. Determinación de la conductividad eléctrica. [Soil improvers and growing media. Determination of electrical conductivity].
Ahmed AF, Yu H, Yang X, Jiang W (2014) Deficit irrigation affects growth, yield, vitamin $\mathrm{C}$ content, and irrigation water use efficiency of hot pepper grown in soilless culture. HortScience 49(6):722-728. https://doi.org/10.21273/HORTSCI.49.6.722

An SK, Lee HB, Kim J, Kim KS (2021) Efficient water management for Cymbidium grown in coir dust using a soil moisture sensor-based automated irrigation system. Agronomy 11:41. https://doi.org/10. 3390/agronomy11010041

Amalfitano C, Del Vacchio L, Somma S, Cuciniello A, Caruso G (2017) Effects of cultural cycle and nutrient solution electrical conductivity on plant growth, yield and fruit quality of 'Friariello' pepper grown in hydroponics. Hortic Sci 44:91-98. https://doi. org/10.17221/172/2015-HORTSCI

Blum A (1996) Crop responses to drought and the interpretation of adaptation. Plant Growth Regul 20:135-148

Caron J, Xu HL, Bernier PY, Duchesne I, Tardif P (1998) Water availability in three artificial substrates during Prunus cystena growth: variable threshold values. J Am Soc Hortic Sci 123:931-936. https://doi.org/10.21273/JASHS.123.5.931

Carvalho RSC, Bastos RG, Souza CF (2018) Influence of the use of wastewater on nutrient absorption and production of lettuce grown in a hydroponic system. Agric Water Manag 203:311-321. https:// doi.org/10.1016/j.agwat.2018.03.028

Cunha-Chiamolera TPL, Urrestarazu M, Cecílio Filho AB, Morales I (2017) Agronomic and economic feasibility of tomato and lettuce intercropping in a soilless system as a function of the electrical conductivity of the nutrient solution. Hortscience 52:1195-1200. https://doi.org/10.21273/HORTSCI12170-17

de Boodt M, Verdonck O (1972) The physical properties of the substrates in horticulture. Acta Hortic. 26:37-44. https://doi.org/10. 17660/ActaHortic. 1972.26.5

de Boodt M, Verdonck O, Cappaert I (1974) Method for measuring the water release curve of organic substrates. Acta Hortic. 37:20542062. https://doi.org/10.17660/ActaHortic.1974.37.20

Evans MR, Stamps RH (1996) Growth of bedding plants in sphagnum peat- and coir dust-based substrates. J Environ Hortic 14:187-190. https://doi.org/10.24266/0738-2898-14.4.187

Gallegos J, Álvaro JE, Urrestarazu M (2020) Container design affects shoot and root growth of vegetable plant. HortScience 55:787794. https://doi.org/10.21273/HORTSCI14954-20

Gallegos-Cedillo VM, Álvaro JE, Capatos T, Hachmann TL, Carrasco G, Urrestarazu M (2018) Effect of pH and silicon in the fertigation solution on vegetative growth of blueberry plants in organic agriculture. HortScience 53:1423-1428. https://doi.org/10.21273/hortsci13342-18

Gallegos-Cedillo VM, Urrestarazu M, Álvaro JE (2016) Influence of salinity on transport of nitrates and potassium by means of the xylem sap content between roots and shoots in young tomato plants. J Soil Sci Plant Nutr 16:991-998. https://doi.org/10.4067/ S0718-95162016005000072

Heuberger H, Livet J, Schnitzler W (2001) Effect of soil aeration on nitrogen availability and growth of selected vegetables-preliminary results. Acta Hortic. 563:147-154. https://doi.org/10.17660/ ActaHortic.2001.563.18

Jobin P, Caron J, Bernier PY, Dansereau B (2004) Impact of two hydrophilic polymers on the physical properties of three substrates and the growth of Petunia_hybrida 'Brilliant pink.' J Am Soc Hortic Sci 129:449-457. https://doi.org/10.21273/JASHS.129.3.0449

Karimzadeh-Soureshjani H, Nezami A, Kafi M, Tadayon M (2019) Responses of two common bean (Phaseolus vulgaris L.) genotypes to deficit irrigation. Agric Water Manag 213:270-279. https://doi.org/10.1016/j.agwat.2018.09.038

Kinoshita T, Yamazaki H, Inamoto K, Yamazaki H (2016) Analysis of yield components and dry matter production in a simplified soilless tomato culture system by using controlled-release fertilizers during summer-winter greenhouse production. Sci Hortic 202:17-24. https://doi.org/10.1016/j.scienta.2016.02.019 
Lee JY, Rahman A, Azam H, Kim HS, Kwon MJ (2017) Characterizing nutrient uptake kinetics for efficient crop production during Solanum lycopersicum var. cerasiforme Alef. growth in a closed indoor hydroponic system. PlosOne 12:e0177041. https://doi.org/ 10.1371/journal.pone.0177041

Londra P, Paraskevopoulou A, Psychogiou M (2018) Hydrological behavior of peat- and coir-based substrates and their effect on begonia growth. Water 10:722. https://doi.org/10.3390/w10060722

Lu J, Shao G, Cui J, Wang X, Keabetswe L (2019) Yield, fruit quality and water use efficiency of tomato for processing under regulated deficit irrigation: a meta-analysis. Agric Water Manag 222:301312. https://doi.org/10.1016/j.agwat.2019.06.008

Maas EV, Hoffman GJ (1977) Crop salt tolerance - current assessment. J Irrig Drain Div 103IR2:115-134

Meerow AW (1995) Growth of two tropical foli-age plants using coir dust as a container media amendment. HortTechnology 5:237239. https://doi.org/10.21273/HORTTECH.5.3.237

Morales I, Martínez-Guitiérrez GA, Escamirosa-Tinoco C, Nájera C, Cunha-Chiamolera TPL, Urrestarazu M (2018) Production and quality of Physalis ixocarpa Brot. Fruit under colored shade netting. HortScience 53:823-828. https://doi.org/10.21273/HORTS CI13100-18

Morales I, Urrestarazu M (2013) Thermography study of moderate electrical conductivity and nutrient solution distribution system effects on grafted tomato soilless culture. HortScience 48:15081512. https://doi.org/10.21273/HORTSCI.48.12.1508

Moya C, Oyanedel E, Verdugo G, Flores MF, Urrestarazu M, Álvaro JE (2017) Increased electrical conductivity in nutrient solution management enhances dietary and organoleptic qualities in soilless culture tomato. HortScience 52:868-872. https://doi.org/10. 21273/hortsci12026-17

Nájera C, Urrestarazu M (2019) Effect of the intensity and spectral quality of LED light on yield and nitrate accumulation in vegetables. HortScience 54:1745-1750. https://doi.org/10.21273/ HORTSCI14263-19

Pozo J, Álvaro JE, Morales I, Requena J, La Malfa T, Mazuela PC, Urrestarazu M (2014) A new local sustainable inorganic material for soilless culture in Spain: granulated volcanic rock. HortScience 49:1537-1541. https://doi.org/10.21273/HORTSCI.49.12.1537

Pozo J, Urrestarazu M, Morales I, Sánchez J, Santos M, Dianez F, Álvaro JE (2015) Effects of silicon in the nutrient solution for three horticultural plant families on the vegetative growth, cuticle, and protection against Botrytis cinerea. HortScience 50:14471452. https://doi.org/10.21273/HORTSCI.50.10.1447

Riviere LM, Foucard JC, Lemaire F (1990) Irrigation of container crops according to the substrate. Sci Hortic 43:339-349. https:// doi.org/10.1016/0304-4238(90)90105-N

Rodríguez D, Reca J, Martínez J, Urrestarazu M (2014a) New adaptive hybrid-automatic irrigation control system for soilless culture. J Irrig Drain Eng 141:04014083. https://doi.org/10.1061/(ASCE) IR.1943-4774.0000853

Rodríguez D, Reca J, Martínez J, Lao MT, Urrestarazu M (2014b) Effect of controlling the leaching fraction on the fertigation and production of a tomato crop under soilless culture. Sci Hortic 179:153-157. https://doi.org/10.1016/j.scienta.2014.09.030

Rodríguez D, Reca J, Martínez J, López-Luque R, Urrestarazu M (2015) Development of a new control algorithm for automatic irrigation scheduling in soilless culture. Appl Math Inf Sci 9(1):47-56. https://doi.org/10.12785/amis/090107

Sambo P, Nicoletto C, Giro A, Pii Y, Valentinuzzi F, Mimmo T, Lugli P, Orzes G, Mazzetto F, Astolfi S, Terzano R, Cesco S (2019) Hydroponic solutions for soilless production systems: issues and opportunities in a smart agriculture perspective. Front Plant Sci 10:923. https://doi.org/10.3389/fpls.2019.00923
Sonneveld C, Straver N (1994) Nutrient solutions for vegetables and flower grow in water or substrates. Tenth Ed. Proefstation voor tuinbouw onder glas te Naaldiwjk, Naaldiwijk, The Netherlands

Sonneveld C, Voogt W (2009) Plant nutrition of greenhouse crops. Springer. Springer Dordrecht Heidelberg, Germany. Pg. London New York. https://doi.org/10.1007/978-90-481-2532-6

Stamps RH, Evans MR (1997) Growth of dieffenbachia maculate 'Camille' in growing media containing sphagnum peat or coconut coir dust. HortScience 32:844-847. https://doi.org/10.21273/ HORTSCI.32.5.844

Urrestarazu M. (2015) Manual práctico de cultivo sin suelo e hidroponia. [Handbook of soilles culture and hydroponics]. Ed. Paraninfo. Madrid, Spain

Urrestarazu M, Álvaro JE, Moreno S, Carrasco G (2008) Remediation of iron chlorosis by the addition of $\mathrm{Fe}-\mathrm{o}, \mathrm{o}-\mathrm{EDDHA}$ in the nutrient solution applied to soilless culture. HortScience 43:1434-1436. https://doi.org/10.21273/HORTSCI.43.5.1434

Urrestarazu M, Gallegos-Cedillo VM, Ferrón-Carrillo F, Guil-Guerrero JL, Lao MT, Álvaro JE (2019) Effects of the electrical conductivity of a soilless culture system on gamma linolenic acid levels in borage seed oil. PlosOne 14:e0207106. https://doi.org/ 10.1371/journal.pone.0207106

Urrestarazu M, Martínez GA, Salas MC (2005) Almond shell waste: possible local rockwool substitute in soilless crop culture. Sci Hortic 103:453-460. https://doi.org/10.1016/j.scienta.2004.06.011

Urrestarazu M, Morales I, Malfa TL, Checa R, Wamser AF, Álvaro JE (2015) Effects of fertigation duration on the pollution, water consumption, and productivity of soilless vegetable cultures. HortScience 50:819-825. https://doi.org/10.21273/HORTSCI.50.6.819

Urrestarazu M, Nájera C, Gea MM (2016) Effect of the spectral quality and intensity of light-emitting diodes on several horticultural crops. HortScience 51:68-271. https://doi.org/10.21273/HORTS CI.51.3.268

Urrestarazu M, Salas MC, Valera D, Gómez A, Mazuela PC (2008b) Effects of heating nutrient solution on water and mineral uptake and early yield of two cucurbits under soilless culture. J Plant Nutr 31:527-538. https://doi.org/10.1080/01904160801895068

Wamser AF, Cecilio Filho AB, Nowaki RHD, Mendoza-Cortez JW, Urrestarazu M (2017) Influence of drainage and nutrient-solution nitrogen and potassium concentrations on the agronomic behavior of bell-pepper plants cultivated in a substrate. PlosOne 12:e0180529. https://doi.org/10.1371/journal.pone.0180529

Wang Y, Liu F, Jensen CR (2012) Comparative effects of deficit irrigation and alternate partial root-zone irrigation on xylem $\mathrm{pH}, \mathrm{ABA}$ and ionic concentrations in tomatoes. J Exp Bot 63:1907-1917. https://doi.org/10.1093/jxb/err370

Waraich EA, Ahmad R, Ashraf MY, Ahmad M (2011) Improving agricultural water use efficiency by nutrient management in crop plants. Acta Agric Scand 61:291-304. https://doi.org/10.1080/ 09064710.2010 .491954

Yadvinder-Singh SSK, Jat ML, Sidhu HS (2014) Improving water productivity of wheat-based cropping systems in South Asia for sustained productivity. Adv Agron 127:157-258. https://doi.org/ 10.1016/B978-0-12-800131-8.00004-2

Yang H, Du T, Qiu R, Chen J, Wang F, Li Y, Wang C, Gao L, Kang S (2017) Improved water use efficiency and fruit quality of greenhouse crops under regulated deficit irrigation in northwest China. Agric Water Manag 179:193-204. https://doi.org/10.1016/j.agwat. 2016.05.029

Publisher's Note Springer Nature remains neutral with regard to jurisdictional claims in published maps and institutional affiliations. 